\title{
Islamization of Knowledge
}

\section{Islamization Through the Sound Arts}

\author{
by Lois Lamyā' àl Fārūqi
}

\section{The Need}

Just as philosophical and religious writings are a verbal expression of the ideology of a people, just as social and economic institutions are determined by that basic ideology, so also music and the sound arts are "translations" of the deepest convictions of a people. They fit into the cultural whole as pieces of a giant mosaic, each tessera reflecting the world view of that people and corresponding to the other expressions of that spirit. Fulfilling this role in the culture, the arts of sound become an important, even crucial, bulwark of a people's heritage.

In English, such aesthetic "translations" of the ideology into pitches and durations are known as "music"; and the term has generally encompassed all forms of sound art, regardless of their intrinsic characteristics or the circumstances of their performance. In Islamic culture, however, there is no term or expression which includes all types of sound art. The term müsiqqa , which is sometimes loosely equated with the English term "music," is certainly inadequate. That Arabic term derived from the Greek has been applied primarily to those forms which, because of context of performance or aesthetic characteristics, were culturally and religiously regarded with some degree of suspicion, or in certain cases, even condemned. The term müsiqa $\bar{a}$ has never included those genres of sound art which were wholeheartedly approved and fostered by the culture, e.g., Qur'anic chant, the adhän, the pilgrimage chants, madih or chanted poetry (shir). Elsewhere I have therefore advocated the use of a new expression, handasah al șawt (al Faruqi 1982:30ff). This designation would cover all the forms of sound art, and thus more truly equate with the term "music" and its cognates in other European languages. It is with that expression and an appreciation of the wide meaning which it implies that this presentation continues.

Handasah al șawt is a cultural phenomemon which can play an impor-

Dr. Lamyā āl Färūqi earned her PhD in Islamic Studies at Syracuse University. She was an expert on Islamic art and music and held several professorships. Her extensive and wideranging publications included An Annotated Glossary of Arabic Musical Terms, and her posthumous magnum opus, jointly authored with her husband, Shahìd Dr. Ismāil āl Färūqi. The Cultural Atlas of Islam. 
tant role in the life of a nation and a people. But this important role cannot be played by any sound art, regardless of its content and form. It must be one growing out of the cultural roots of its people and expressing the message of the cultural complex from which it arises. The fostering of such a sound art or musical tradition is crucial to any people at any period of history. But it is especially important to the Muslim peoples today as they face the drastic cultural changes of our contemporary world, extensive migratory displacement, and the unprecedented incidence of cultural interaction and alien influences on their life and culture. Handasah al șawt is an important aspect of that cultural core which is ultimately the only significant defense against cultural alienation or annihilation. It is an important factor in strengthening the Islamic cultural core, or, put another way, a crucial ingredient in the process of Islamization of the ummah.

Islamization, as a process of renewal and creativity, has been on the lips of Muslim activists and reformers for decades. Yet few writers and thinkers have pursued Islamization with any understanding of its implications for handasah al sawt or the sound arts. We read of the Islamization of knowledge, the Islamization of the field of economics, the Islamization of social theory, the Islamization of political thought, and the Islamization of psychology. We even see the effects of the Islamization of dress codes and eating habits. All of these movements and changes are attempts to produce the requisite Islamic core and identity from which the Muslim peoples can encounter or avoid, adapt or ignore, accept or reject the influences of contemporary life which are inevitably thrust upon them. Without this Islamization, maintaining a positive and actively creative cultural identity becomes doubtful, and even our very existence as a viable community is threatened.

Despite their concern for Islamization of many other aspects of culture, contemporary Muslims seem strikingly unaware of the de-Islamization which is evidenced in the aesthetic components of their lives. Many of them fill their homes with French provincial furniture and figural painting produced for a 19th century European clientele. They entertain themselves with the products of the Western or Hindu movie and television industries, which are anything but Islamic in content and form. And radios and cassette machines fill the sound waves of their environment with the latest musical expressions of a non-Islamic cultural message. Equally disturbing is the response from the other end of the liberal-conservative spectrum. When one asks any of the superconservatives about Islamic musical expression, they hasten to disassociate themselves from the discussion as though not only the listening to music, but even the discussion of it might have a contaminating effect. An exchange regarding the wide variety of new religious songs from Egypt elicits the response from one devout Muslimah that she will no longer listen to any type of music for it may be disapproved by Islam. The presentation of musical knowledge 
is never included on the agenda of any Islamic conference. And it is impossible to count the number of times Muslims have asked me whether music as such is halāl ("legitimate") or harām ("illegitimate").

It is true that the older generation of Muslims, whether living in the socalled Muslim nations or in regions of the non-Muslim world, still react Islamically with reserve or negation to the musical expressions coming to them from non-Muslim sources through the means of radios, television sets, the cinema, or the sound and video cassette. Though they rarely analyze the reasons for their lack of interest or rejection of these artistic expressions, they have a kind of "gut feeling" that the music from the alien sources-whether that of the latest "pop" stars or the contemporary classical music composers of Europe and America-does not "speak" to them or is not carrying a message they wish to hear. Their early involvement with a vibrant Islamic sound art tradition has oriented them to other types of musical expression. What of their offspring, however, who have been born and raised in the world of Elvis Presley, the Rolling Stones, and Arnold Schonberg? Those Muslims, who will soon join the adult community, have had little strengthening of their identity through an Islamic musical acculturation, since most of the sound arts which they encounter are derived from an alien culture and ideology. This will certainly have serious consequences in the future as the cultural identity of Muslims is threatened with erosion or obliteration.

If an Islamic core personality is recognized as crucial, it is impossible to overlook the importance of every aspect of culture that can contribute to this personality. The sound arts, being ever present and working in exceedingly subtle ways on the individual and the community, are a crucial feature of the acculturating process. It is imperative that Muslims be awakened to the importance of Islamization in every aspect of their lives, including that of the handasah al șawt contributions.

\section{Background Explanations for Our Sound Art Attitudes}

There are a number of reasons that may have contributed to the apprehensive neglect of the sound arts and the lack of active concern for their Islamization.

A. One reason for this aesthetic disinterest and complacency is the common belief among Muslims that music is a "forbidden" pleasure which they can only participate in and enjoy with some measure of guilt or misgiving. This results from the centuries-old controversy in the culture on the advantages or disadvantages of certain types of sound art. Despite countless statements and treatises from some of the Muslim world's leading brains (e.g., 
al Shāfíi 1906:VI, 215; al Ghazālī n.d.:II; 1901-1902; Ibn Taymiyyah 1966:II, 295-330; and the late rector of Al Azhar University, Mạ̣mūd Shaltūt 1960:355-359), ${ }^{1}$ the controversy has never been settled conclusively, and confusion regarding the status of the musical arts pertains to the present day in many Muslim minds.

B. Contemporary attitudes about the sound arts also result from

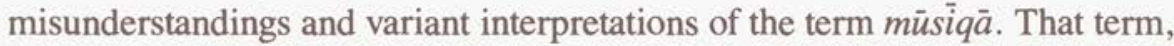
as was mentioned earlier, should be understood as applying only to certain genres or types of handasah al sawt, generally the more secularly oriented and instrumentally embellished forms. It never connotes, as does the English term "music," such sound arts as tartil al Qurän and the adhän, even though they evidence the artistic organization of pitched sounds which is generally associated with the English term "music." Though the fact has not been consistently understood by all Muslims and certainly not by non-Muslims, the controversy over the legitimacy of music in Islamic culture was never meant to involve all the sound arts. The legitimacy of the non-müsiqua genres was not questioned by the jurists, nor were all müsiqqã genres categorically condemned by them (see al Faruqi 1982 for a fuller treatment of this matter). The rejection of certain types of sound art therefore should not be viewed as a cultural or religious prohibition of all types of handasah al șawt. It represents instead attempts by the leadership and the community to direct musical expression and appreciation toward those forms that were compatible with the ideology and ethos of Islam and in harmony with its customs and traditions.

C. A third reason for the disinterest in the Islamization of the handasah al sawt genres is fear that involvement with any type of müsiqa $\bar{a}$ is prohibited by Allah ta'ãlā in the Holy Qur'ān. This is of course false; there is no Qur'anic passage that condemns the sound arts generally or even those genres properly labeled as müsiqua . Nor does it mention them. The only passages relevant to the arts of sound are those commanding the cantillation or vocalization of the Qur'an (e.g. 25:32; 73:4), although proponents of müsiqqa as well as those who condemn it, have often sought to read into other passages support for their arguments (Roychoudhury 1957:Chapter II).

D. A fourth reason for the lack of concern for the sound arts in the writings of contemporary proponents of Islamization relates to what many Muslims suppose to be the stance of the hadith literature on musical expression. Antagonists of musical expression cite certain of its passages to support their

\footnotetext{
' See also Roychoudhury 1957; Robson 1938; Ibn al Qaysarāni 1390/1970; al Nābulusī 1302/1884; and al Färüqi 1985, for additional materials on the controversy.
} 
contention that the Prophet (SAAS) condemned music. ${ }^{2}$ On the other hand, protagonists of musical expression point to other ahädith which imply support for their position. ${ }^{3}$ Both sides have sought to substantiate their stance rather than to analyze the issue in order to penetrate to the deeper truth behind the apparent contradictions. Certainly the Prophet (SAAS) was not so inconsistent as to condemn a practice on one occasion and condone the same practice on another. There must therefore have been variant circumstances that necessitated his differing responses. This may have resulted from the nature of the musical expression itself. In other words, was it aesthetically or musically beautiful, fitting, and morally uplifting? Or the Prophet's variant reactions may have been due to the circumstances of its performance. Was it presented at a suitable time, in a suitable place, and under conditions that were conducive to the well-being of the participating individual and community?

E. A fifth reason for ignoring the potential of the sound arts in the Islamization process may be the common failure or inability of contemporary Muslims to distinguish between the sound art expressions which are Islamically significant and those which could lead to de-Islamization. Many contemporary Muslims appreciate certain types of sound art and reject others instinctively, without thinking to ask themselves why the former is preferable to the latter. This may be adequate in an environment where non-Islamic cultural influences are absent or statistically negligible. But such an environment is a "pipe dream" in the second half of the 20th century, regardless of the part of the world in which one lives. Some Muslims have attempted therefore to erect an "iron curtain" around themselves, to isolate their families and children from those forms of sound art that might be instruments of de-Islamization. With the prevalence of modern communication technology in every town and village,

\footnotetext{
${ }^{2}$ For example, the Prophet (SAAS) is reported to have put his fingers to his ears so as not to hear a particular performance (Abū Däwüd 1396/1950:40th Book on Adab, Chap. 52). This is then interpreted to be a condemnation of all musiqu. Another hadith reports the following: "No one lifts up his voice in singing but God sends to him 2 devils on his two shoulders, beating with their heels on his breast while he sings refrains" (reported by Abü Umämah but not in the al Bukhäri or Muslim collections of ahädith). See al Qaysarani 1390/1970:75-95, for other ahädith implying discouragement of various genres of handasah al sawt.

${ }^{3}$ According to 'A'ishah, "Allah's Apostle (ȘAAS) came to my house while two girls were singing beside me the songs of Bu' ath...Then Abü Bakr came and spoke to me harshly saying, 'Musical instruments of Satan near the Prophet (ȘASS)? Allah's Apostle (ȘAAS) turned his face toward him and said, 'Leave them.' " (al Bukhäri 1971:37). Another incident given on the authority of "A'ishah is the following: "On the days of Minā (10th, 11th, 12th of Dhul-Hijjah) Abū Bakr (RAA) came to her while two young girls were beating the tamborine and the Prophet (SAAS) was lying covered with his clothes. Abū Bakr (RAA) scolded them and the Prophet (SAAS) uncovered his face and said to Abü Bakr, 'Leave them, for these days are the days of "Id and the days of Minã." (al Bukhäri 1971:55-56). Compilations of the hadith materials on müsiqā and samát can be found in Roychoudhury 1957:66-70; al Ghazäli 1901-1902; Ibn al Qaysarāni 1390/1970; Robson 1938; see also Yüsuf al Qaraḍāwi n.d.:300ff.
} 
such attempted isolation is rarely if ever successful. Others meet the challenge by trying to prohibit all the sound arts, regardless of their characteristics. In such cases, the resulting artistic vacuum is inevitably filled by non-Islamic forms of music, which invade the minds of the less thoroughly Islamized members of the community-its youth. It is time that Muslims realized the consequences of such a mental and aesthetic "cop out."

F. A sixth factor contributing to the failure actively to pursue Islamization of the sound arts can be described as a lack of awareness of Islamic significance in this regard. For example, many Muslims are not conscious of the importance of Qur'anic recition or "chant" in their aesthetic lives. They are of course aware of its religious and ethical significance, but they are oblivious of its role in shaping their aesthetic and musical sense and the degree to which it has determined the characteristics of the other genres of sound art that have been developed and performed throughout the Muslim world. Of course, there are differences between the musical traditions of various regions of the Muslim world, but one cannot fail to notice that many genres of handasah al sawt performed and enjoyed by Muslims from Morocco to the southern Philippines evidence a number of core characteristics based on that prime model of the Islamic sound arts - the recitation of the Qur'ān (see al Fārūqi 1983-84). Incorporation into our daily lives and activities of sound arts that evidence this Qur'ānic influence and determination, as well as the creation of new similarly based examples, could provide tremendous potential for aesthetic Islamization. It is a potential that has never been actively harnessed. It is a potential waiting to be tapped by contemporary Muslims who have already experienced political and economic invasons of their lands, and are now well on their way to experiencing the results of a perhaps even more devastating cultural and aesthetic invasion of their soul.

\section{Importance of Handasah al Sawt for Islamization}

In what ways, you may ask, can handasah al sawt, determined by the Qur'anic principles, contribute to Islamization?

A. First of all, the way Islamic sound arts can have a powerful effect is by implementing their role as "translations" into sound of the Islamic message of tawhid. Those sound arts representative of that message should never be regarded as mere entertainment. In fact, they are examples of creativity which remind the listener of his/her commitment to Allah (subhāanahu wa taālā). They do not focus attention on man, on this world and its activities, or on depiction of human emotions. They have a higher goal, and their abstract rather than programmatic qualities give convincing evidence of that goal. 
Whenever examples of sound art expression become too sensuous or musically descriptive of earthly or human qualities, rather than a succession of sound patterns that leads the hearer to contemplate the higher Reality, Muslims have sought to correct or reject them. The Islamic organization of musical elements should reflect a series of infinite patterns in sound which, in their modular units, their repetitive aspects, their intricacy, and their never-ending quality, would be perfect complements of the literary "patterns" of the Quran itself and its "translation" into visual arabesques. Such sound reinforcements of the message of tawhid cannot but enhance the Islamization process of the individual and of the community.

B. A second way in which handasah al șawt can contribute to Islamization is by uniting Muslims, whatever their national identity, whatever their ethnic background, and wherever they may live, around a common and indigenous aesthetic sound tradition. Islamization must be widespread if it is to be effective in developing and maintaining an Islamic religio-cultural identity. That can never be achieved through nationalistic movements, linguistic shuübiyyah, or ethnic chauvinism. It must be based on Qur'anic principles that can fire the imagination of all Muslims. This is, in fact, the situation that pertained in earlier times; and there are still remnants of the influence of the Qur'ānic recitation on many performances of both the müsiqqa and other handasah al șawt genres throughout the Muslim world. Unfortunately, however, the alien aesthetic influences today are much more pervasive an influence than they were in earlier times. Contemporary technological advances such as the video- and audio-cassette, satellite relays, and the transistor radio have brought a sound art invasion based on other ideologies into the most remote corners of the Muslim world, for the ready consumption and indoctrination of mass audiences. If the sound arts compatible with the goals of a tawhidbased art are not encouraged and supported, the resultant lacunae in Islamic existence will certainly be filled-are, in many instances, already filled!with the non-tawhid sound arts.

C. The tawhid-inspired sound arts could not only contribute to Islamization by helping to musically unite the Muslim world on a global level, a contribution which we might label as the horizontal dimension of their Islamization importance. They can also unite the Muslims on a vertical dimension. By this is meant that a common sound art tradition, fostered and supported by the Muslim community of any nation or region, would contribute towards breaking down the barriers that presently divide such a community into disparate strata.

Muslim society-in whatever nation of the Muslim world one investigates - has been truncated in recent centuries by two opposing systems of education. One is the traditional Islamic system operative in the kuttäb or elementary/secondary school and the more advanced institutions of Islamic 
learning. The other is modeled after the educational establishments of Western Europe and America. This bifurcation of the educational system has resulted in a polarized society in which the graduates of one system have little in common with the graduates of the other. Lack of understanding, political strife, frustration, instability, and social isolation are the results of this unfortunate educational legacy from the colonial period. It permeates all fields of thought, learning, and action; and makes it impossible for the two segments of any Muslim society meaningfully to communicate and cooperate with each other. It has been a cause of much lack of cohesion in Post-Revolutionary Iran, and it hovers as a possible igniter of disastrous conflict in many Muslim nations. This potential for trouble is not just a difference pertaining to political or economic views. It is also a difference involving social customs, leisure activities, and expressions of the visual and sound arts. All of these aspects of life and culture have suffered reorientation through the prolonged colonial and post-colonial periods. Unless all of them-including the sound arts - are re-Islamized and reunited in a vertical way in our societies, we can look forward to a continued cleavage between the two diversely educated segments of Muslim society and to the consequences that such a situation portends.

\section{Whence A Solution?}

From where will the impetus for an Islamization of the contemporary sound arts and an awareness of its importance come? Certainly, we cannot depend on the Muslim governments to initiate such a move, for their officials are for the most part unaware of, or indifferent to, the benefits to Islamic global horizontal unity and national vertical unity that can be derived from such Islamization. In addition, most of the present governments are politically too unstable to risk moves toward Islamization, which might open them to attacks from Muslim conservatives, on the one hand, or from secularists, on the other.

The international Islamic organizations are no less susceptible to political constraints, which incapacitate them from implementing any Islamization of the sound arts. In addition, they have perennially suffered from the common Muslim world disease of institutional "radical surgery" This practice so inhibiting of progress, is, unfortunately, evident in most of the institutions of the Muslim peoples. Instead of building organizations which are strong enough and sufficiently stable to continue and progress despite changes of leadership, we Muslims tend to build battlefields for leadership strife and destruction. Instead of establishing institutions with a strife-insulated pattern for leadership succession, we seem able only to create individuals who rise to power for a brief "splash" of achievement, before being cut down by an opponent. 
The successor immediately practices "radical surgery" on all that his predecessor had accomplished - cancelling, undoing, and redirecting whatever progress had been made. The result is not a move ahead for the institution and for those who should benefit from it, but a regression. Soon this leader is also replaced and another application of "radical surgery" follows. If the institution survives at all - and many of them do not-the 'ummah is cheated of benefit.

If governments and international institutions are not to be expected to instigate and carry out the Islamization of the sound arts, from where can such a movement originate? It can come only from those individual Muslims who realize the importance of imparting tawhid, not only to their religious rituals, but also to every other aspect of their lives. And it can come only when they act on that realization and commitment. It is "people power" that carried Islam to the four corners of the earth. It is a similar "power" that will produce Islamization of the sound arts. Only such a grass-roots motivation and call for Islamization will be lasting and significant.

Certainly, as Muslims, we must aspire to being tawhid-oriented in a comprehensive way. We must activate our din to involve our total existence and commitment. This should include the aesthetic creations of which Allah made His vicegerent capable, and the beautiful things of life of which Allah made His vicegerent susceptible and appreciative. ${ }^{4}$ Only when we have accomplished this as well as all other forms of Islamization, will we have achieved the unity of religion and life that Islam was meant to engender.

4 Say: Who hath forbidden The beautiful (gifts) of God, Which $\mathrm{He}$ hath produced For His servants,

And the things, clean and pure, (Which He hath provided) For sustenance?

Say: They are, in the life Of this world, for those Who believe, (and) purely For them on the Day Of Judgment. Thus do We
Explain the Signs in detail

For those who understand. Say: The things that my Lord Hath indeed forbidden are: Shameful deeds, whether open Or secret: sins and trespasses Against truth or reason; assigning Of partners to God, for which $\mathrm{He}$ hath given no authority; And saying things about God Of which ye have no knowledge.

(Qur'ān 7:32-33) 


\section{References Cited}

Abū Dāwũd

Sunan. 4 vols., edited by M. M. 'Abd al Hamid. Cairo.

al Bukhāri, Muhammad Ibn Isma il

Sahīh al Bukhāri, Vol. II. Translated by Muhammad Muhsin Khān. Mad inah: Islamic University, 1971.

al Fārūqi, Lois Lamyā (Ibsen)

"The Shari' ah on Music and Musicians," Islämic Thought and Culture, ed.

Isma' ì R. al Fārūqi. Washington, D.C.: International Institute of Islamic Thought, 1982, pp. 27-52.

"Factors of Continuity in the Musical Cultures of the Muslim World," Progress Reports in Ethnomusicology I (2), 1983-84, pp. 1-18.

"Music, Musicians and Muslim Law," Asian Music XVII (1), 1985, pp. 3-36. al Ghazāili, Abū Hāmid Muhammad Ibn Muhammad

Ihyä' 'Ulüm al Dìn. Vol. II. Cairo: Mațba' ah al Istiqamah, n.d.

Inyä' 'Ulüm al Din, section tr. by Duncan B. Macdonald as "Emotional Religion in Islam as Affected by Music and Singing," Journal of the Royal Asiatic Society, 1901-02, Part I, 195-252; Part II, 705-748; Part III, 1-28.

Ibn al Qayasarāní, Abū al Fạ̣l Muhammad Ibn Tāhir Ibn ‘ Alī Ibn Ạ̣mad al Maqdisí al Shaybāni

Kitāb al Samā: Edited by Abū al Wafā al Marāghī. Cairo: High Committee for Islamic Affairs, Government of Egypt, 1390/1970.

Ibn Taymiyyah, Taqia al Dịn Abū al 'Abbās Aḥmad Ibn 'Abd al Halīm

"Kitāb al Samā̄ wal Raqs," Majmū'ah al Rasāill al Kubrā. Vol. II. Cairo:

Mațaba' ah Muhammad 'Ali Șubayḥ, 1966, pp. 295-330.

al Nābulusí, 'Abd al Ghani

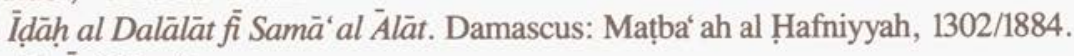
al Qaradāwi, Yūsuf

The Lawful and the Prohibited in Islam. Translated by Kamal El-Helbawy, M. Moinuddin Siddiqui, and Syed Shukry. Indianapolis: American Trust Publications, n.d. (First published in Arabic in 1960).

Robson, James

Tracts on Listening to Music. London: The Royal Asiatic Society, 1938. Roychoudhury, M. L.

Music in Islam, reprinted from the Journal of the Royal Asiatic Society, Letters. Calcutta: H. Bhattacharya, 1957.

al Shāfi' $\bar{i}$, Abū 'Abdullah Muḥammad Ibn Idris

Kitāb al Umm, bi Riwàyah al Rabī'i Ibn Sulaymān. Cairo: Būlāq, 1906.

Shaltūt, Mạmmūd

Al Fatāwā. Cairo: Dār al Shurūq, 1960, pp. 355-359. 